\title{
Gene and functional up-regulation of the BCRP/ABCG2 transporter in hepatocellular carcinoma
}

\author{
Caecilia HC Sukowati ${ }^{*}$, Natalia Rosso ${ }^{1}$, Devis Pascut ${ }^{1}$, Beatrice Anfuso ${ }^{1}$, Giuliano Torre ${ }^{2}$, Paola Francalanci ${ }^{2}$, \\ Lory S Crocè ${ }^{1,3}$ and Claudio Tiribelli ${ }^{1,3}$
}

\begin{abstract}
Background: The Breast Cancer Resistance Protein (BCRP/ABCG2) is one member of $A B C$ transporters proteins super family responsible of drug resistance. Since data on ABCG2 expression in liver malignances are scanty, here we report the expression of $A B C G 2$ in adult human hepatocellular carcinoma (HCC) in both in vivo and in vitro models with different degree of malignancy.

Methods: In cell lines derived from human hepatocellular carcinoma, ABCG2 gene expression was assessed by reverse transcription quantitative real time PCR and function by Hoechst 33342 efflux assay; protein content was assessed by SDS-PAGE Western blot.

Results: ABCG2 expression was found to be highest in the most undifferentiated cell lines, and this was related with a higher functional activity. ABCG2 expression was sensitive to antineoplastic drugs since exposure to $5 \mu \mathrm{M}$ doxorubicin for 24 hours resulted in significant up-regulations of ABCG2 in all cell lines, particularly in those lines with low basal $A B C G 2$ expression $(p<0.01)$. The gene expression was also investigated in 51 adult liver tissues with HCC and related cirrhosis; normal liver tissue was used as control. ABCG2 gene expression was higher in HCC than both cirrhotic paired tissue and normal tissue. This up-regulation was greater $(p<0.05)$ in pathological poorly differentiated grade G3/G4 than in well-differentiated G1/G2 HCC.

Conclusions: Our results suggest a correlation of $A B C G 2$ gene expression and differentiation stage both in human and HCC derived cell lines. The rapid up-regulation of ABCG2 to exposure to doxorubicin emphasizes the importance of this transporter in accounting for drug resistance in liver tumors.
\end{abstract}

Keywords: Liver cancer, Drug resistance, Gene expression, Doxorubicin

\section{Background}

Primary liver cancer is one of the most common cancers in the world and the third cause of cancer-related death [1]. Hepatocellular carcinoma (HCC) accounts for around 85-95\% of all PLC cases. Targeted systemic therapies to treat HCC patients with advanced stages had become one of urgent needs in the management of HCC [2]. However, systemic therapies also have been faced many obstacles, such as drug toxicity and drug resistance.

\footnotetext{
* Correspondence: caecilia.sukowati@csf.units.it

${ }^{1}$ Centro Studi Fegato, Fondazione Italiana Fegato, Bld Q AREA Science Park Basovizza, Trieste, Italy

Full list of author information is available at the end of the article
}

The Breast Cancer Resistance Protein (ABCG2/BCRP/ MXR) is one member of the ATP-Binding Cassette (ABC) transporters superfamily proteins [3]. One of the key functions of $\mathrm{ABC}$ transporter is related with the cell resistance to exposure of external compounds, exporting the drug out of the cells thus maintaining the intracellular drug compound below toxic level. ABCG2 protein is widely expressed in tissues, mainly in placenta, epithelium of small intestine and colon, liver canalicular membrane and breast [4]. Furthermore, ABCG2 is also expressed in the epithelium of the prostate and bladder, endocervical cells of uterus, kidney tubules and others tissues [5].

The association between ABCG2 and cancer has been extensively studied. The ABCG2 protein was observed in a wide variety of tumors [6] and shown to be involved in

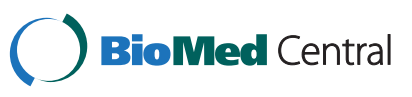


the cancer cells resistance to many chemotherapeutic agents $[7,8]$. However, even though there are several reports of ABCG2 in liver cancer [9-12], it is still needed to be expanded and its correlation with clinical finding is important to be explored. The ABCG2 expression was found to be high in HCC [10] and was reported to increase following chemotherapy in hepatoblastoma patients [13]. In glioma, ABCG2 expression is related with pathological grade, tissues differentiation and resistance to mitoxantrone [14].

In recent studies, ABCG2 expression has been also associated with stem cells and cancer stem cells, both in circulating and solid cancers. Side population (SP) of stem cells is a population of cells having the ability to export Hoechst 33342 dye, an activity related with cells resistance [15]. In HCC, the SP cells sorted from several cell lines were associated with the metastatic potentials and therapeutic-resistance [16]. Zhou et al. demonstrated that the ABCG2/Bcrp1 is the molecular determinant for SP $[17,18]$ and SP of hepatic oval cells was also defined by ABCG2/BCRP1 in the rat model [19]. Furthermore, cells expressing ABCG2 might play a central role in hepatocarcinogenesis, in which $\mathrm{ABCG}^{+}$cells could generate both $\mathrm{ABCG}^{+}$and $\mathrm{ABCG}^{-}$cells, whereas ABCG2 ${ }^{-}$cells bore only ABCG2 cells [20].

Collectively these studies indicated the relevance of ABCG2 in several human malignancies and its association with drug resistance and cells differentiation. We here report on the ABCG2 mRNA level and activity in both in vitro and in vivo models consisting of human hepatic cell lines and human samples of HCC to investigate the role of this transporter, particularly its role in drug resistance issue in liver cancer.

\section{Methods \\ Samples \\ Cell lines}

Human liver cell lines IHH, HepG2, HuH-7 and JHH-6 were used as in vitro models of HCC cell lines with different degree of morphologic differentiation. The immortalized hepatocyte line IHH was kindly provided by Dr. Trono (Lausanne, Switzerland) [21] while human HCC cell lines HuH-7 (JCRB0403) and JHH-6 (JCRB1030) were obtained from the Japan Health Science Research Resources Bank (HSRRB, Tokyo, Japan). The HepG2 cell line was obtained from the Istituto Zooprofilattico Sperimentale della Lombardia e dell'Emilia Romagna (IZSLER, Brescia, Italy).

The IHH cells were grown in DMEM-F12 medium supplemented with $10 \%(\mathrm{v} / \mathrm{v})$ fetal bovine serum (FBS), $1 \%$ antibiotics, $1 \%$ L-glutamine, $1 \mu \mathrm{M}$ dexamethasone and $5 \mu \mathrm{g} / \mathrm{mL}$ insulin. The HepG2 and $\mathrm{HuH}-7$ cells were grown in DMEM medium (high glucose) supplemented with $10 \%(\mathrm{v} / \mathrm{v})$ FBS, 1\% L-glutamine and $1 \%$ antibiotics.
The JHH-6 cells were grown in Williams' E medium supplemented with $10 \%(\mathrm{v} / \mathrm{v}) \mathrm{FBS}, 1 \% \mathrm{~L}$-glutamine and $1 \%$ antibiotics. The cultures were maintained at $37^{\circ} \mathrm{C}$ in a humidified $5 \% \mathrm{CO}_{2}$ incubator and when they reached $80 \%-90 \%$ confluence they were routinely expanded by $0.05 \%$ trypsin detachment.

\section{Human tissue samples}

Human liver tissues were collected from HCC patients undergoing liver resections or orthotopic liver transplantations and normal donor liver in the similar age group as control. A total of 51 (23 HCC, 21 cirrhosis, 7 normal tissues) liver tissues were analyzed. Fifteen paired samples HCC and cirrhosis were obtained from the same patient ( $70 \%$ of all HCC tissues analyzed). The tissues were snap-frozen in liquid nitrogen and stored in $-80^{\circ} \mathrm{C}$ before further processing. The diagnosis of patients was established on international criteria together with its Edmondson Steiner HCC grading [22] and other clinical findings. Informed consent to participate to the study was obtained from each patient or by a legal representative and the protocol was approved by the ethical committee of the University of Trieste.

\section{In vitro cytotoxicity test}

The cytotoxic effects of doxorubicin hydrochloride (Dox), verapamil hydrochloride, Hoechst 33342 (Sigma-Aldrich, St Louis, USA) and Rhodamine 123 (Rho123; Invitrogen, Milan, Italy) were assessed by 3-(4,5-Dimethyl-2thiazolyl)-2,5-diphenyl-2H-tetrazolium bromide (MTT) dye reduction test [23]. The cells were seeded in concentration 20,000 cells $/ \mathrm{cm}^{2}$ in 24-well plates for the corresponding time. The dose of Dox, verapamil, Hoechst, and Rho123 ranged from 0 to $10.0 \mu \mathrm{M}, 0$ to $20 \mu \mathrm{M}, 0$ to $5 \mu \mathrm{g} /$ $\mathrm{mL}$, and 0 to $20 \mu \mathrm{g} / \mathrm{mL}$, respectively. For Dox cytotoxicity test, the exposure time was 24 hours, whereas for verapamil, Hoechst and Rho123 the exposure time was tested at 30, 90 and 180 minutes as the required time to perform the dye exclusion assay. The absorbance of the untreated cells was taken as $100 \%$ survival.

\section{Total RNA isolation and reverse transcription}

Total RNA from cell lines and tissues samples was extracted using the TriReagent solution (Sigma-Aldrich) according to the manufacture's protocol. The RNA pellet was dissolved in nuclease-free water and stored at $-80^{\circ} \mathrm{C}$ until further analysis. RNA was quantified at 260 $\mathrm{nm}$ in a Beckman Coulter $\mathrm{DU}^{\circledR} 730$ spectrophotometer (Fullertone, CA, USA). The RNA purity was evaluated according the MIQE guidelines [24] by measuring the ratio A260/A280 with appropriate purity values between 1.8 and 2.0. The integrity of RNA was assessed on standard 1\% agarose/formaldehyde gel. The reverse transcription of $1 \mu \mathrm{g}$ of total RNA was performed with an iScript 
cDNA synthesis Kit (Bio-Rad, Milan, Italy) according to the manufacture's suggestions. A total of $20 \mu \mathrm{L}$ volume reaction was conducted in a thermocycler (Gene Amp PCR System 2400, Perkin-Elmer, Boston, MA, USA) at $25^{\circ} \mathrm{C}$ for $5 \mathrm{~min}, 42^{\circ} \mathrm{C}$ for $30 \mathrm{~min}, 85^{\circ} \mathrm{C}$ for $5 \mathrm{~min}$. The cDNA was conserved at $-20^{\circ} \mathrm{C}$ until used.

\section{Quantitative real time RT-PCR (RT-qPCR)}

The RT-qPCR of gene ABCG2 and ABCB1 was performed according to the iQ SYBR Green Supermix protocol (Bio-Rad). PCR amplification was carried out in $15 \mu \mathrm{L}$ reaction volume containing $25 \mathrm{ng}$ of cDNA, $1 \mathrm{x}$ iQ SYBR Green Supermix (100 mM KCl; $40 \mathrm{mM}$ Tris-HCl; pH 8.4; $0.4 \mathrm{mM}$ each dNTP; $50 \mathrm{U} / \mathrm{mL}$ iTaq DNA polymerase; $6 \mathrm{mM} \mathrm{MgCl}_{2}$; SYBR Green I; $20 \mathrm{mM}$ fluorescein; and stabilizers) and $250 \mathrm{nM}$ gene specific sense and anti-sense primers (Table 1). Reactions were run and analyzed on a Bio-Rad iQ5 multi color real-time PCR detection system (IQ5 software version 3.1) together with reference genes. Cycling parameters were determined and analyzed using the Pfaffl modification of the $\Delta \Delta$ Ct equation with taking accounts to the efficiency of the reaction [25]. Primer sets were designed using the Beacon Designer 7.9 (Premier Biosoft International, Palo Alto, CA, USA) across two exons to avoid contamination of genomic DNA and reference genes 18S-rRNA and $\beta$-actin were used to normalize target gene expression. Melting curve analysis and agarose gel electrophoresis were carried out to asses templates specificity.

\section{Western blot}

After $5 \mu \mathrm{M}$ Dox treatment for 24 hours, cells were washed with PBS at room temperature. The protein was extracted using cell lysis buffer (PBS containing 1\% v/v of a protease inhibitor cocktail and $2 \mathrm{mM}$ phenylmethylsulfonylfluoride). Protein concentration was determined by copper (II) sulphate solution and bicinchonic acid (Sigma-Aldrich) protein assay following the manufacturer's instructions.

A total of $30 \mu \mathrm{g}$ protein were size-separated, together with molecular weight standard by SDS-PAGE using a Mini Protein III Cell (Bio-Rad, Hercules, CA, USA). After SDS-PAGE, proteins were electro-transferred with a semi-dry blotting system onto immune-blot PVDF membranes using a Mini Trans-Blot Cell (Bio-Rad).
Membrane was incubated overnight at $4^{\circ} \mathrm{C}$ with targeted antibodies in T-TBS buffer (Tris $20 \mathrm{mM}$, Tween 20, $0.2 \%, \mathrm{NaCl} 500 \mathrm{nM}, \mathrm{pH} 7.5)$. The peroxidase reaction was obtained by exposure of membrane in the ECL-Plus Western blot detection system solutions (ECL Plus Western blotting Detection Reagents, GE-Healthcare Bio-Sciences, Italy). List of antibodies was described in Table 2.

\section{Hoechst 33342 efflux assay}

The activity of ABCG2 in cell lines IHH, HepG2, HuH-7 and JHH-6 was assessed using Hoechst 33342 efflux assay with modification from previous report [27]. Single cells suspension and monolayer cells were given sterile 1 to $20 \mu \mathrm{M}$ final concentration of verapamil incubated for 30 minutes in $37^{\circ} \mathrm{C}$. After incubation, $5 \mu \mathrm{g} / \mathrm{mL}$ Hoechst 33342 was added, and the cells incubated for 90 minutes in $37^{\circ} \mathrm{C}$. The reaction was stopped by incubating the cells on ice for 5 minutes. The Hoechst 33342 efflux was measured by spectrofluorometer (Jasco FP-770, Maryland, USA and Hidex Chameleon - Driver 4.34, Turku, Finland) for suspension and monolayer cells, respectively. The measurement was performed on $355 \mathrm{~nm}$ excitation and $460 \mathrm{~nm}$ emission wavelength. To confirm the ABCB1 activity, the internal accumulation of Rho123, was performed by FACSCalibur flow cytometer (Beckton Dickinson, NJ, USA). A total of 10,000 events were analyzed per sample.

\section{Statistical analysis}

Box plot graphics and statistical analysis were constructed using software SigmaPlot Version 11.0 (Systat Software, Inc., Chicago, USA). The student's $t$ test was performed for statistical comparison between groups. Value of $\mathrm{p}<0.05$ was regarded as statistically significant.

\section{Results}

Modulation of the ABCG2 gene and protein expression by doxorubicin

To investigate the ABCG2 expression according to cell differentiation, 4 human-derived hepatic cell lines with different degree of differentiation were analyzed. The expression of immortalized normal human hepatocytes IHH was defined as control 1.00. The highest level of ABCG2 folds mRNA expression compared to IHH was

Table 1 List of primer sequences for the quantification of specific genes by RT-qPCR in hepatic cell lines and clinical samples tissues

\begin{tabular}{lllll}
\hline Gene & Acc. no. & Primer forward & Primer reverse & Ref. \\
\hline ABCG2 & NM_004827 & TATAGCTCAGATCATTGTCACAGTC & GTTGGTCGTCAGGAAGAAGAG & This study \\
ABCB1 & NM_000927 & TGCTCAGACAGGATGTGAGTTG & AATTACAGCAAGCCTGGAACC & This study \\
3-actin & NM_001101 & CGCCGCCAGCTCACCATG & CACGATGGAGGGGAAGACGG & This study \\
18S-rRNA & NR_003286 & TAACCCGTGAACCCCATT & CCATCCAATCGGTAGTAGCG & [26] \\
\hline
\end{tabular}


Table 2 List of antibodies

\begin{tabular}{lll}
\hline Antibody & Clone & MW kDa \\
\hline ABCG2/BCRP & BXP53 (Abcam, Cambridge, MA, USA) & 72 \\
ABCB1/MDR1 & C219 (Abcam, Cambridge, MA, USA) & 170 \\
Actin & A2066 (Sigma-Aldrich, St. Louis, MO, USA) & 42 \\
Anti rabbit lgG peroxidase & P0448 (Dako, Glostrup, Denmark) \\
Anti rat lgG peroxidase & P0450 (Dako, Glostrup, Denmark) \\
Anti mouse lgG peroxidase & P0260 (Dako, Glostrup, Denmark) \\
\hline
\end{tabular}

observed in the most undifferentiated cells JHH-6 (76.27 \pm 6.00 ), followed by the more differentiated cells HepG2 $(53.52 \pm 19.06)$ and $\mathrm{HuH}-7(35.07 \pm 10.96)$ with $\mathrm{p}<0.01$. In line with the mRNA results, $\mathrm{ABCG} 2$ protein $(72 \mathrm{kDa})$ was detected in tumoral cell lines $\mathrm{HuH}-7, \mathrm{HepG} 2$, and $\mathrm{JHH}-6$, but not or very weak in $\mathrm{IHH}$ (Figure 1A). The
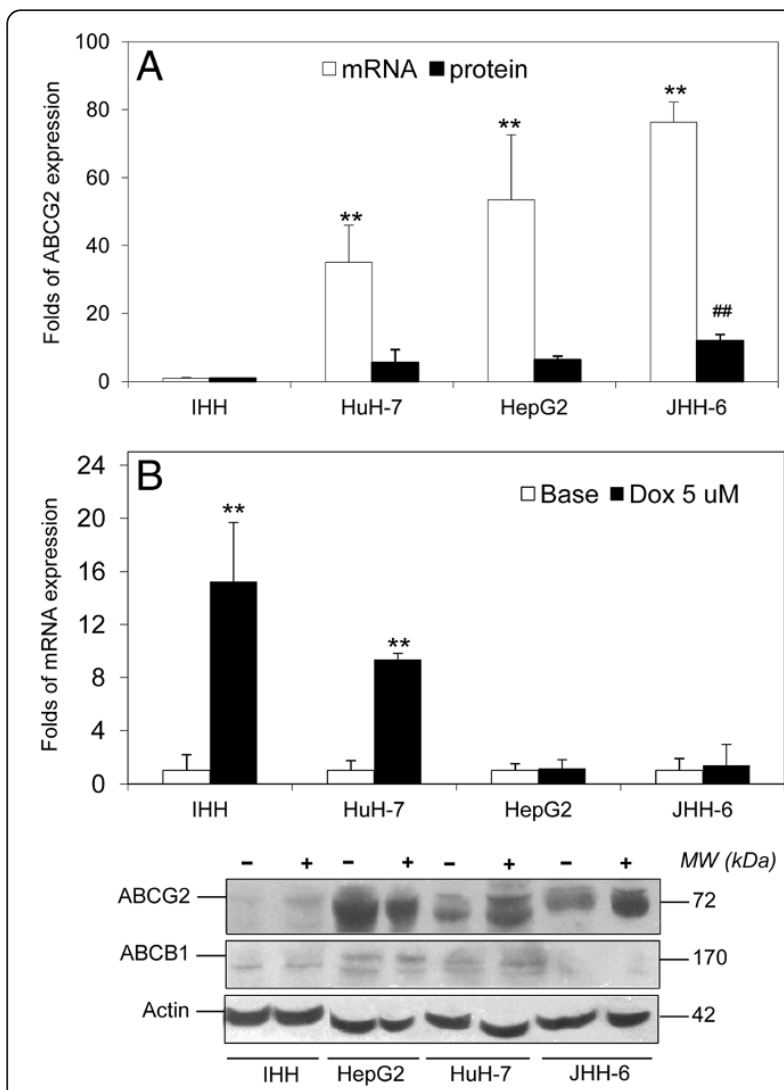

Figure 1 The expression of ABCG2 in hepatic cell lines. A. The basal ABCG2 mRNA and protein expression in human hepatic cell lines $\mathrm{HH}, \mathrm{HuH}-7, \mathrm{HepG} 2$ and $\mathrm{JHH}-6$. The data represented the mean \pm SD of minimum three independent experiments. Statistical student's $t$ test: mRNA ${ }^{* *} \mathrm{p}<0.01$ to $\mathrm{HH}$, protein ${ }^{\# \#} \mathrm{p}<0.01$ to $\mathrm{HH}$. B. The folds of ABCG2 mRNA up-regulation after exposure to $5 \mu \mathrm{M}$ Dox for 24 hours compared to basal expression considered (1.00). Statistical students' $t$ test: ${ }^{* *} p<0.01$ to basal expression of each cell lines. The mRNA expression was normalized to reference genes 18S-rRNA and $\beta$-actin. Protein blot showing a representative Western Blot of ABCG2 (72 kDa) and ABCB1 (170 kDa) protein.

Symbol: - control (basal level), + Dox. protein expression in $\mathrm{JHH}-6$ is $11.5 \pm 1.5$ folds higher compared to $\mathrm{IHH}(\mathrm{p}<0.01)$.

We then assessed the effect of ABCG2 expression after exposure to Dox. When exposed to $5 \mu \mathrm{M}$ Dox for 24 hours, $50 \%$ cell population in all cell lines tested died. In the surviving cells of each cell line, the exposure to Dox induced an up-regulation of ABCG2 mRNA. Of notice the extent of the up-regulation was inverse to the basal level of expression as $\mathrm{IHH}$ and $\mathrm{HuH}-7$ showed a significant increment of gene expression (15.25 \pm 4.45 and $9.36 \pm 0.48$ folds, respectively, $\mathrm{p}<0.01$ ) as compared to HepG2 and JHH- 6 which the expression was unchanged $(1.14 \pm 0.68$ and $1.38 \pm 1.58$ folds, respectively). In line with the gene expression, ABCG2 protein was weakly detected in $\mathrm{IHH}$ cells at basal condition, but it became detectable after exposure to Dox. The same occurred in $\mathrm{HuH}-7$ while no difference was observed in JHH-6 cells where the treatment did not induce a significant overexpression of the transporter. However, even though there was a striking ABCG2 up-regulation compared to their basal level, the level of ABCG2 in IHH after Dox did not reach the basal level of HuH-7, HepG2, and $\mathrm{JHH}-6$, still about a half of basal $\mathrm{HuH}-7$ expression (Figure 1B).

\section{The functional activity of ABCG2}

To define the activity of the ABCB1 and ABCG2 protein in the cell lines, the Hoechst 33342 efflux assay was determined. Preliminary experiments showed no effect on cell viability (MTT test) by verapamil, Hoechst and Rho123, to all cell lines, on working concentration of 10 $\mu \mathrm{M}, 5 \mu \mathrm{g} / \mathrm{mL}$, and $10 \mathrm{ug} / \mathrm{mL}(96.6 \pm 5.3 \%, 90.6 \pm 7.4 \%$,

\section{Table 3 The efflux capacity of the HCC cell lines in} exporting Hoechst 33342

\begin{tabular}{llcl}
\hline HCC lines & \multicolumn{1}{l}{ Hoechst $33342(\boldsymbol{\mu g} / \mathbf{m L})$} & \\
\hline & 2.5 & 5.0 & 10.0 \\
HuH-7 & $100.0 \pm 6.4$ & $88.4 \pm 5.5$ & $53.0 \pm 2.8$ \\
HepG2 & $100.0 \pm 6.2$ & $74.7 \pm 3.1$ & $51.2 \pm 2.8$ \\
JHH-6 & $100.0 \pm 5.8$ & $80.1 \pm 2.1$ & $53.7 \pm 4.0$
\end{tabular}

The increase of Hoechst 33342 concentration decreased intracellular dye accumulation in all HCC cell lines tested. The intracellular dye intake of $2.5 \mu \mathrm{g} /$ $\mathrm{mL}$ as lowest dye concentration was considered as $100.0 \%$. The data represented the mean \pm SD of three independent experiments. 
and $94.9 \pm 8.1 \%$, respectively). As control, we evaluated also the level of basal ABCB1 expression in these cell lines. The ABCB1 mRNA expression in $\mathrm{IHH}$ and $\mathrm{JHH}-6$ were really low, more than 1000 times lower compared to those of $\mathrm{HuH}-7$ and HepG2. ABCB1 protein expression was shown in Figure 1B.

As shown in Table 3, the increase of Hoechst concentration $(2.5-10.0 \mu \mathrm{g} / \mathrm{mL})$ increased the activity of these two transporters to export dyes. This was defined by the decrease of Hoechst intracellular dye accumulation.

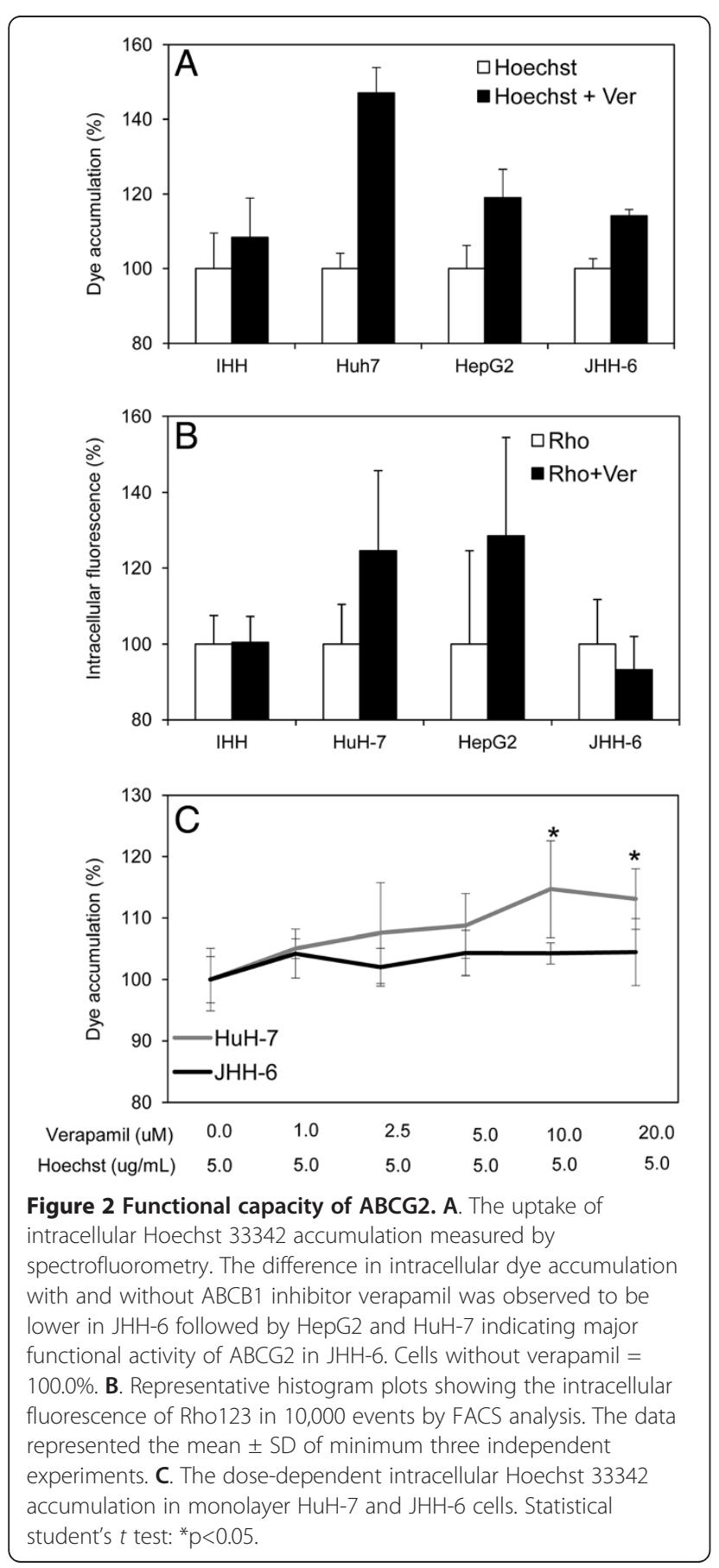

These evidences showed the capacity of both transporters to efflux the dyes out of the cells as a mechanism of cells toxicity defense mechanism.

Since the extracellular extrusion Hoechst 33342 is accounted by two $\mathrm{ABC}$ proteins (ABCB1 and ABCG2), to establish the relative role of $\mathrm{ABCG} 2$ the assay was also performed in the presence of verapamil, a potent $A B C B 1$ but a weak $A B C G 2$ inhibitor [30]. In the HCC cell lines which have both ABCB1 and ABCG2, the lowest differential Hoechst fluorescence signal between cells with and without verapamil was found in cells JHH-6, indicating the ABCG2 in this cell line is dominantly responsible of the dye efflux. The result of Rho123 efflux measurement by FACS confirmed the functionality of ABCB1 was observed higher in HuH-7 and HepG2 (Figure 2A). A dose dependent Hoechst 33342 internal dye accumulation with the presence 1 to $20 \mu \mathrm{M}$ verapamil in monolayer cells gave similar result (Figure 2B).

\section{ABCG2 expression in vivo}

To confirm the data found in the cell lines in an in vivo series, we measured the quantity of ABCG2 mRNA in human samples collected from patient with $\mathrm{HCC}$ and cirrhosis. The ABCG2 mRNA levels in the 51 tissues samples were estimated by RT-qPCR and expressed in arbitrary units (au); a sample obtained from normal human liver was considered as $1.00 \mathrm{au}$. As shown in Figure 3A, ABCG2 expression was found to be rather variable in all groups and in particular in HCC patients. The ABCG2 expression were found to be more restricted in normal and cirrhotic tissues compared to HCC

When HCC patients were divided according to the Edmondson Steiner HCC grading system, the expression of ABCG2 was found to be higher in $\mathrm{HCC}$ with poorly differentiated HCC G3/G4 ( $n=6)$ as compared to welland moderately-differentiated HCC G1/G2 (n=13) $(\mathrm{p}<0.05)$. In 15 paired samples, the up-regulation of ABCG2 in HCC compared to its cirrhotic tissue was consistently found to be higher in G3/G4 HCC (ratio $3.24 \pm 2.08$ folds) than in G1/G2 HCC (ratio $1.25 \pm 1.06$ folds) $(\mathrm{p}<0.01)$ as shown in Figure 3B. This significance was not observed for ABCB1 gene. There was no correlation of ABCG2 with other clinical findings such as MELD and CTP score, etiology, alpha fetoprotein and albumin level, and vascular invasion.

\section{Discussion}

The non-responsiveness of cancer cells to chemotherapeutic regiments has been a major obstacle in the treatment of cancers. The survival rate for HCC patients in advanced stages which could not treated with surgical procedures (including liver transplantation) has not been changed for 30 years [28]. One of the important issues 

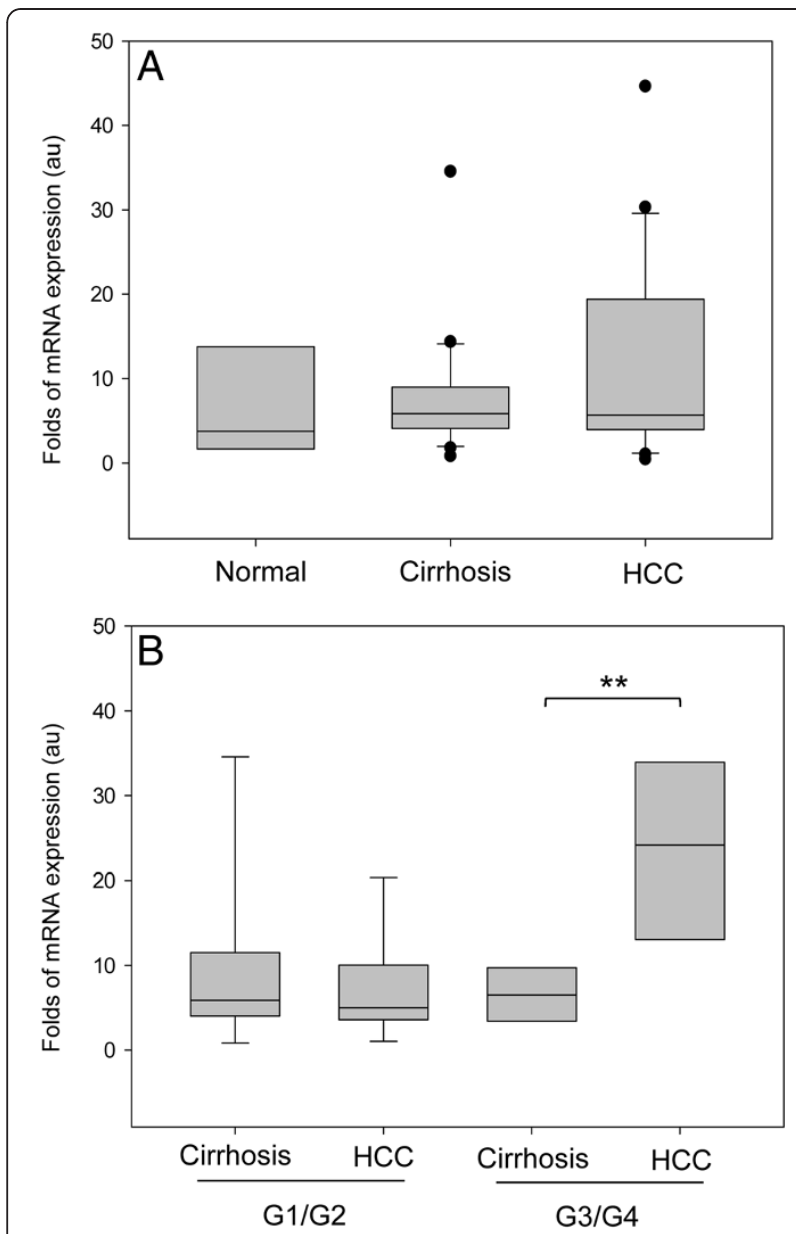

Figure 3 The expression of ABCG2 mRNA in HCC tissues. A. The general distribution of ABCG2 mRNA expression in HCC and normal liver. Normal liver $(N ; n=7)$, cirrhotic tissue of HCC $(n=21)$, and tumoral tissue of HCC $(n=23)$. B. The up-regulation of ABCG2 mRNA in the HCC compared to its cirrhotic paired tissues from 15 paired individuals with histological G1/G2 and G3/G4 grade. The mRNA expression was normalized to reference genes $\beta$-actin and 18S-rRNA. A normal liver was considered as 1.0 au. Statistical student's $t$ test: ${ }^{* *} p<0.01$.

in multidrug resistance in cancer is the high expression of $\mathrm{ABC}$ transporters proteins, including ABCG2.

Due to the inconclusive data on the role of ABCG2 in $\mathrm{HCC}$ we assessed the functional and gene expression of this $\mathrm{ABC}$ transporter in two different but related systems such as a series of human derived liver cell lines and patients with HCC and cirrhosis. For the in vitro model 4 differently differentiated hepatic cell lines were used. Three derived from HCC while one originates from a normal adult liver. The ABCG2 mRNA expression in tumoral lines was higher than in immortalized normal hepatocyte $(\mathrm{IHH})$ and this was paralleled by the protein contents. Of notice was the effect observed when the cells were exposed to $5 \mu \mathrm{M}$ Dox. This treatment induced an up-regulation of both gene expression and protein content in all cell lines, but the up-regulation was inversely proportional to the basal level of expression. This behavior suggests that in the presence of toxic drug, ABCG2 is induced to export the drug from the cell and to prevent cytotoxicity as one of the major defense mechanisms and that this effect is maximal when the basal level of the expression is low. The data we observed in HepG2 cells agree with a previous report in which ABCG2 mRNA was up-regulated in Dox-resistant HepG2 [29].

To assess the activity of ABCG2 in cancer cell lines, we performed a functional assay using the Hoechst 33342 test. The efflux of Hoechst 33342 is accounted by both ABCG2 and ABCB1 transporters, and verapamil had been shown to effectively inhibit ABCB1 but not ABCG2 [30]. The addition of verapamil resulted in the increase of intracellular Hoechst 33342 in the well differentiated HepG2 and $\mathrm{HuH}-7$ cells but not in the poorly differentiated cells (JHH-6). This data points to the conclusion that in the poorly differentiated HCC cell line, the efflux is mainly depend on the ABCG2 activity while in the more differentiated ones, drug export is also accounted by the activity of $A B C B 1$. This conclusion is in line with very high ABCB1 expression in both HepG2 and $\mathrm{HuH}-7$ cells. This finding indicates that a high expression of ABCG2 transcription is associated with functional role of the transporter which results in the protection of the cell from doxorubicin-induced cytotoxicity.

To compare the data obtained in vitro, we studied the ABCG2 mRNA expression in samples of adult normal liver and tissues obtained from HCC patients. There are several limitations in this type of studies such as the effect of the different treatments to which each patient undergoes before being considered for hepatic resection or transplantation. Our data in human tissues samples show a rather high variation in ABCG2 expression, as expected. The large variations of intra- and inter-groups ABCG2 expression observed in this study had also been reported in acute leukemia [31], breast cancer [32] and lung cancer [33]. We believe that these variations are likely linked to several factors such as age, sex, type of the drugs, duration of the treatments, severity of the diseases, and many others. In line with this conclusion is the observation that when we compared the expressions of normal adult liver with that obtained from children, ABCG2 expression was higher in the adults (data not shown), suggesting that ABCG2 expression is agerelated and dependent to drug exposure which obviously increases with age.

The overall distribution showed that the expression of the ABCG2 mRNA was slightly higher and more dispersed in HCC and cirrhotic tissues as compared to normal tissues, in line with a previous report [10]. Interestingly, the ABCG2 mRNA expression was higher in 
the HCC than in the surrounding cirrhotic tissue in about $60 \%$ of HCC patients. Of notice was the observation that this up-regulation was consistently observed in poorly differentiated pathological grade G3/G4 than in G1/G2 HCC tissue. This is different from what described by Gupta et al. who reported in 3 specimens of liver cancers that both the mRNA and protein level of ABCG2 were decreased [34]. The discrepancy suggests that the ABCG2 expression is variable and dependent by the tissue type, even in the single individual due to variability of HCC tissues profile. A relationship between cell differentiation and ABCG2 expression had been previously reported in other cell lines. A high level of functional ABCG2 was detected in undifferentiated human embryonic cells and decreased during cellular differentiation [35]. In hematopoietic system, the ABCG2 expression is confined to the most immature progenitor cells and downregulated at the committed progenitor level [36]. Recent data showed that knock-down of ABCG2 inhibited breast cancer and lung cancer cells proliferation, suggesting the role of ABCG2 in maintenance the cancer cells [37].

Our finding reemphasized the importance of intrinsic factors like age, differentiation, and disease status in the expression of drug-transporters in human tissues. Our data expand the previous report showing that ABCG2 protein and mRNA were higher in HCC [10] and that in hepatoblastoma patients the transporter was upregulated following chemotherapy [13]. For the ABCG2 and pathological grade of cancer, our data in HCC is concordant with those observed in glioma [14].

\section{Conclusions}

Our findings demonstrated an higher expression of the ABCG2 in liver diseases compared to normal tissue and possibly more important, in $\mathrm{HCC}$ where the genetic and functional up-regulation is more marked in less differentiated tumors. The up-regulation of ABCG2 observed in response to drug therapy underlines the importance of this transporter to account for the drug resistance and points the needs to explore its expression in liver diseases, HCC in particular.

\section{Competing interests}

The authors declare that they have no competing interests.

\section{Authors' contributions}

CHCS conducted the experiments and wrote the article; NR, DP, and BA performed experiments; PF, GT, and LSC read and approved the text; CT read, edited and approved the text. All authors read and approved the final manuscript.

\section{Acknowledgments}

CHCS was supported by a fellowship of the Italian Ministry of Foreign Affairs of the Istituto Italiano di Cultura, Jakarta, Indonesia - This work was supported by a grant from the Italian Liver Foundation. The authors thank Drs. U. Baccarani, P. Lupo, C. Avellini, V. Lanzilotti, and N. De Manzini for their help in the collecting of clinical materials.

\section{Author details}

${ }^{1}$ Centro Studi Fegato, Fondazione Italiana Fegato, Bld Q AREA Science Park Basovizza, Trieste, Italy. ${ }^{2}$ Ospedale Pediatrico Bambino Gesù, Rome, 00100 , Italy. ${ }^{3}$ Department of Medicine, University of Trieste, Trieste 34100, Italy.

Received: 23 July 2012 Accepted: 1 November 2012

Published: 15 November 2012

\section{References}

1. Parkin DM, Bray F, Ferlay J, Pisani P: Estimating the world cancer burden: Globocan 2000. Int J Cancer 2001, 94:153-156.

2. Villanueva A, Llovet JM: Targeted therapies for hepatocellular carcinoma. Gastroenterology 2011, 140:1410-1426.

3. Dean M, Hamon Y, Chimini G: The human ATP-binding cassette (ABC) transporter superfamily. J Lipid Res 2001, 42:1007-1017.

4. Maliepaard M, Scheffer GL, Faneyte IF, van Gastelen MA, Pijnenborg AC, Schinkel AH, van De Vijver MJ, Scheper RJ, Schellens JH: Subcellular localization and distribution of the breast cancer resistance protein transporter in normal human tissues. Cancer Res 2001, 61:3458-3464.

5. Fetsch PA, Abati A, Litman T, Morisaki K, Honjo Y, Mittal K, Bates SE: Localization of the ABCG2 mitoxantrone resistance-associated protein in normal tissues. Cancer Lett 2006, 235:84-92.

6. Diestra JE, Scheffer GL, Catala I, Maliepaard M, Schellens JH, Scheper RJ, Germa-Lluch JR, Izquierdo MA: Frequent expression of the multi-drug resistance-associated protein BCRP/MXR/ABCP/ABCG2 in human tumours detected by the BXP-21 monoclonal antibody in paraffinembedded material. J Pathol 2002, 198:213-219.

7. Litman T, Brangi M, Hudson E, Fetsch P, Abati A, Ross DD, Miyake K, Resau $J H$, Bates SE: The multidrug-resistant phenotype associated with overexpression of the new ABC half-transporter, MXR (ABCG2). J Cell Sci 2000, 113(Pt 11):2011-2021.

8. Burger $H$, Nooter $\mathrm{K}$ : Pharmacokinetic resistance to imatinib mesylate: role of the $A B C$ drug pumps $A B C G 2$ (BCRP) and $A B C B 1$ (MDR1) in the oral bioavailability of imatinib. Cell Cycle 2004, 3:1502-1505.

9. Cusatis G, Gregorc V, Li J, Spreafico A, Ingersoll RG, Verweij J, Ludovini V, Villa E, Hidalgo M, Sparreboom A, Baker SD: Pharmacogenetics of ABCG2 and adverse reactions to gefitinib. J Natl Cancer Inst 2006, 98:1739-1742.

10. Sun Z, Zhao Z, Li G, Dong S, Huang Z, Ye L, Liang H, Qu J, Ai X, Zhang W, Chen $X$ : Relevance of two genes in the multidrug resistance of hepatocellular carcinoma: in vivo and clinical studies. Tumori 2010, 96:90-96.

11. Kamiyama N, Takagi S, Yamamoto C, Kudo T, Nakagawa T, Takahashi M, Nakanishi K, Takahashi H, Todo S, Iseki K: Expression of ABC transporters in human hepatocyte carcinoma cells with cross-resistance to epirubicin and mitoxantrone. Anticancer Res 2006, 26:885-888.

12. Barnes SN, Aleksunes LM, Augustine L, Scheffer GL, Goedken MJ, Jakowski $A B$, Pruimboom-Brees IM, Cherrington NJ, Manautou JE: Induction of hepatobiliary efflux transporters in acetaminophen-induced acute liver failure cases. Drug Metab Dispos 2007, 35:1963-1969.

13. Vander Borgth S, van Pelt J, van Malenstein H, Cassiman D, Renard M, Verslype C, Libbrecht L, Roskams TA: Up-regulation of breast cancer resistance protein expression in hepatoblastoma following chemotherapy: A study in patients and in vitro. Hepatol Res 2008, 38:1112-1121.

14. Jin Y, Bin ZQ, Qiang H, Liang C, Hua C, Jun D, Dong WA, Qing L: ABCG2 is related with the grade of glioma and resistance to mitoxantone, a chemotherapeutic drug for glioma. J Cancer Res Clin Oncol 2009, 135:1369-1376.

15. Hu C, Li H, Li J, Zhu Z, Yin S, Hao X, Yao M, Zheng S, Gu J: Analysis of ABCG2 expression and side population identifies intrinsic drug efflux in the HCC cell line MHCC-97L and its modulation by Akt signaling. Carcinogenesis 2008, 29:2289-2297.

16. Shi GM, Xu Y, Fan J, Zhou J, Yang XR, Qiu SJ, Liao Y, Wu WZ, Ji Y, Ke AW, Ding ZB, He YZ, Wu B, Yang GH, Qin WZ, Zhang W, Zhu J, Min ZH, Wu ZQ: Identification of side population cells in human hepatocellular carcinoma cell lines with stepwise metastatic potentials. J Cancer Res Clin Oncol 2008, 134:1155-1163.

17. Zhou S, Schuetz JD, Bunting KD, Colapietro AM, Sampath J, Morris JJ, Lagutina I, Grosveld GC, Osawa M, Nakauchi H, Sorrentino BP: The ABC transporter Bcrp1/ABCG2 is expressed in a wide variety of stem cells and is a molecular determinant of the side-population phenotype. Nat Med 2001, 7:1028-1034.

18. Zhou S, Morris JJ, Barnes Y, Lan L, Schuetz JD, Sorrentino BP: Bcrp1 gene expression is required for normal numbers of side population 
stem cells in mice, and confers relative protection to mitoxantrone in hematopoietic cells in vivo. Proc Natl Acad Sci USA 2002, 99:12339-12344

19. Shimano K, Satake M, Okaya A, Kitanaka J, Kitanaka N, Takemura M, Sakagami M, Terada N, Tsujimura T: Hepatic oval cells have the side population phenotype defined by expression of ATP-binding cassette transporter ABCG2/BCRP1. Am J Pathol 2003, 163:3-9.

20. Zen Y, Fujii T, Yoshikawa S, Takamura H, Tani T, Ohta T, Nakanuma Y: Histological and culture studies with respect to $A B C G 2$ expression support the existence of a cancer cell hierarchy in human hepatocellular carcinoma. Am J Pathol 2007, 170:1750-1762.

21. Schippers IJ, Moshage H, Roelofsen H, Muller M, Heymans HS, Ruiters M, Kuipers F: Immortalized human hepatocytes as a tool for the study of hepatocytic (de-)differentiation. Cell Biol Toxicol 1997, 13:375-386.

22. Edmondson HA, STEINER PE: Primary carcinoma of the liver: a study of 100 cases among 48,900 necropsies. Cancer 1954, 7:462-503.

23. Mosmann T: Rapid colorimetric assay for cellular growth and survival: application to proliferation and cytotoxicity assays. J Immunol Methods 1983, 65:55-63.

24. Bustin SA, Benes V, Garson JA, Hellemans J, Huggett J, Kubista M, Mueller R, Nolan T, Pfaffl MW, Shipley GL, Vandesompele J, Wittwer CT: The MIQE guidelines: minimum information for publication of quantitative real-time PCR experiments. Clin Chem 2009, 55:611-622.

25. Pfaffl MW: A new mathematical model for relative quantification in real-time RT-PCR. Nucleic Acids Res 2001, 29:e45.

26. Schmittgen TD, Zakrajsek BA: Effect of experimental treatment on housekeeping gene expression: validation by real-time, quantitative RT-PCR. J Biochem Biophys Methods 2000, 46:69-81.

27. Plumb JA, Milroy R, Kaye SB: The activity of verapamil as a resistance modifier in vitro in drug resistant human tumour cell lines is not stereospecific. Biochem Pharmacol 1990, 39:787-792.

28. Blum HE: Molecular targets for prevention of hepatocellular carcinoma. Dig Dis 2002, 20:81-90.

29. Li G, Chen X, Wang Q, Xu Z, Zhang W, Ye L: The roles of four multi-drug resistance proteins in hepatocellular carcinoma multidrug resistance. J Huazhong Univ Sci Technolog Med Sci 2007, 27:173-175.

30. Zhang Y, Gupta A, Wang H, Zhou L, Vethanayagam RR, Unadkat JD, Mao Q: BCRP transports dipyridamole and is inhibited by calcium channel blockers. Pharm Res 2005, 22:2023-2034.

31. Ross DD, Karp JE, Chen TT, Doyle LA: Expression of breast cancer resistance protein in blast cells from patients with acute leukemia. Blood 2000, 96:365-368.

32. Burger H, Foekens JA, Look MP, Meijer-van Gelder ME, Klijn JG, Wiemer EA, Stoter G, Nooter K: RNA expression of breast cancer resistance protein, lung resistance-related protein, multidrug resistance-associated proteins 1 and 2, and multidrug resistance gene 1 in breast cancer: correlation with chemotherapeutic response. Clin Cancer Res 2003, 9:827-836.

33. Kawabata S, Oka M, Soda H, Shiozawa K, Nakatomi K, Tsurutani J, Nakamura Y, Doi S, Kitazaki T, Sugahara K, Yamada Y, Kamihira S, Kohno S: Expression and functional analyses of breast cancer resistance protein in lung cancer. Clin Cancer Res 2003, 9:3052-3057.

34. Gupta N, Martin PM, Miyauchi S, Ananth S, Herdman AV, Martindale RG, Podolsky R, Ganapathy V: Down-regulation of BCRP/ABCG2 in colorectal and cervical cancer. Biochem Biophys Res Commun 2006, 343:571-577.

35. Apati A, Orban TI, Varga N, Nemeth A, Schamberger A, Krizsik V, Erdelyi-Belle B, Homolya L, Varady G, Padanyi R, Karaszi E, Kemna EW, Nemet K, Sarkadi B: High level functional expression of the ABCG2 multidrug transporter in undifferentiated human embryonic stem cells. Biochim Biophys Acta 2008, 1778:2700-2709.

36. Scharenberg CW, Harkey MA, Torok-Storb B: The ABCG2 transporter is an efficient Hoechst 33342 efflux pump and is preferentially expressed by immature human hematopoietic progenitors. Blood 2002, 99:507-512.

37. Chen Z, Liu F, Ren Q, Zhao Q, Ren H, Lu S, Zhang L, Han Z: Suppression of ABCG2 inhibits cancer cell proliferation. Int J Cancer 2010, 126:841-851.

doi:10.1186/1471-230X-12-160

Cite this article as: Sukowati et al:: Gene and functional up-regulation of the BCRP/ABCG2 transporter in hepatocellular carcinoma. BMC Gastroenterology 2012 12:160.

\section{Submit your next manuscript to BioMed Central and take full advantage of:}

- Convenient online submission

- Thorough peer review

- No space constraints or color figure charges

- Immediate publication on acceptance

- Inclusion in PubMed, CAS, Scopus and Google Scholar

- Research which is freely available for redistribution 